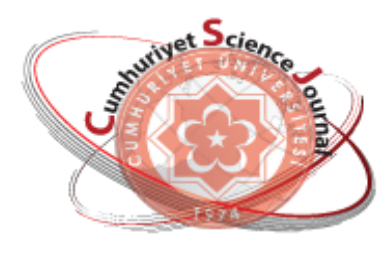

e-ISSN: 2587-246X

ISSN: $2587-2680$

\section{Cumanoryet Seienee Journal $\cos 7$}

Cumhuriyet Sci. J., Vol.39-2(2018) 431-438

\title{
Contamination Measurements of Patient's Lead-Insulated Rooms After I- 131 and LU-177 PSMA Treatment via Sweeping Test
}

\author{
Kubra HARMAN ${ }^{1}$, Tuğba DEMIRBAY ${ }^{2 *}$, Mustafa DEMIR ${ }^{3}$ \\ ${ }^{1}$ Sinop University, Faculty of Engineering and Architecture, Nuclear Energy Engineering, Sinop, TURKEY \\ ${ }^{2}$ Ylldiz Technical University, Faculty of Science \& Letters, Physics Department, Istanbul, TURKEY \\ ${ }^{3}$ Istanbul University, Cerrahpaşa Medical School, Nuclear Medicine Department, Istanbul, TURKEY
}

Received: 30.11.2017; Accepted: 05.04.2018

http://dx.doi.org/10.17776/csj.359939

\begin{abstract}
I-131 and Lu-177 PSMA radionuclides have been widely used in the field of nuclear medicine to treat thyroid cancer for many years. In this treatment, the patients whose dose rate measurements are less than $3 \mathrm{mR} / \mathrm{h}$ are generally discharged from the lead-insulated rooms where they are hospitalized. The aim of our study is to evaluate the contamination measurements of these rooms after I-131 and LU-177 PSMA treatment and to ensure radiation safety. A sweeping test was carried out by using Whatman papers (10x10 $\mathrm{cm} 2 \mathrm{in}$ size) to take samples from designated areas of these rooms in which three patients were treated with Lu-177 PSMA and four patients were treated with the I-131 radionuclide. Whatman papers are placed inside different tubes to prevent external contamination. Afterward, counting procedure was taken to the tubes for one minute by using the gamma counter which has different calibration factors both for Lu-177 and I-131 radionuclides. For the background extraction, one-minute counting test was applied to one of the Whatman papers that were not used for sweeping and background value was then obtained. It was statistically understood that the highest contamination rate was observed on the surface of toilet potteries in each room. As a result, ventilation of the room, meticulous cleaning of contaminated areas and the sweeping test must be implemented in each room where the patients are treated with radionuclides before the treatment of other patients.
\end{abstract}

Keywords: Sweeping test, Lu-177 radionuclide, I-131 radionuclide, Surface contamination, radiation contamination.

\section{I-131 ve LU-177 PSMA Tedavisi Sonrası Hastaların Kurşun İzolasyonlu Odalarının Süpürme Testi ile Kontaminasyon Ölçümleri}

\footnotetext{
Özet: I-131 ve Lu-177 PSMA radyonüklidleri, uzun yıllardır nükleer tıp alanında tiroid kanseri tedavisinde yaygın şekilde kullanılmaktadır. Tedavi süresince, doz hızı ölçümleri $3 \mathrm{mR} /$ saat'in altında olan hastalar genellikle hastaneye kaldırıldıkları odadan taburcu edilirler. Bu çalışmanın amacı hastanın kurşun izolasyonlu odalarının I-131 ve LU-177 PSMA tedavisinden sonra kontaminasyon ölçümlerini değerlendirmek ve radyasyon güvenliğini sağlamaktır. Süpürme testi, Lu-177 PSMA ile tedavi edilen üç hasta ve I-131 radyonüklid ile tedavi edilen dört hastaya ev sahipliği yapan odanın belirlenmiş alanlarından numuneler almak için 10x10 $\mathrm{cm}^{2}$ ebatlı Whatman kağıtları kullanılarak gerçekleştirildi. Numunelerin alınması için kullanılan Whatman kağıtları, dış kontaminasyonu önlemek için farklı tüplerin içine yerleştirildi. Daha sonra, tüplerin sayım işlemi hem Lu-177 hem de I-131 radyonüklidleri için farklı kalibrasyon faktörlerine sahip olan gama sayacı kullanılarak bir dakika boyunca yapıldı. Background çıkarma amacıyla, kullanılmayan temiz Whatman kağıtlarından birine bir dakikalık sayım testi uygulanmıştır. Bu testten sonra I-131 ve Lu-177 PSMA ile tedavi edilen hastaların sonuçları değerlendirildi. İstatistiksel olarak sırasıyla I-131 ve Lu-177 PSMA radyonüklidleri ile tedavi edilen hastalar için en yüksek kontaminasyonun bir tuvalet seramik yüzeyinde gözlendiği anlaşıldı. Sonuç olarak, yeni hastaların tedavisinden önce olası kontaminasyonların önüne geçmek için radyonüklidler ile
} 
tedavi edilen hastaların odalarında havalandırma, kirlenmiş bölgelerin titizlikle temizlenmesi ve süpürme testi gibi işlemler yapılmalıdır.

Anahtar Kelimeler: Süpürme Testi, Lu-177 Tadyonüklid, I-131 Radyonüklid, Yüzey Kontaminasyonu, Radyasyon Kontaminasyonu.

\section{INTRODUCTION}

In recent years, the Lu-177 PSMA treatment which emerges as a result of the connection of the Lu-177 radioisotope with the prostatespecific membrane antigen (PSMA) inhibitor has been successfully applied in the treatment of prostate cancer $[1,2]$ and smart molecules have been developed accordingly. Smart molecules are the most effective substances which are developed for cancer diagnosis and its treatment. These molecules have an ability to detect and irradiate the cancerous tissue inside the human body. PSMA and prostate can be given as an example for the smart molecules that can detect an approximate amount and the locations of neuroendocrine and thyroid cancers with DOTATE by PET BT examinations after the attachment of these molecules to Ga-68. These agent molecules bind to Lu-177 and are given to the patients through the vein where only the tumor cells are irradiated. It is especially applied to the patients who suffer from lymph node or distant organ metastases [3]. Since the gamma rays are released due to the decay of $\mathrm{Lu}-177$ radionuclide, it has an immense importance in terms of radiation safety. According to the standard treatment protocols available in Australia and Europe, patients are hospitalized in lead insulated private rooms at the hospital for 13 days just after 7400 Mbq Lu-177 peptide treatment. Ideal conditions for the discharge of the patients after radionuclide treatment are defined in accordance with the IAEA regulations. The patients whose dose rate are below than defined limit which is determined by the local atomic energy authorities can be discharged from the hospital. In Turkey, TAEK's legal limit for the discharge of patients treated with radionuclide therapy is $30 \mathrm{micro} \mathrm{Sv} / \mathrm{h}$.

Radioactive I-131 was used in the treatment of hyperthyroidism in the 1940s, and its use became widespread when it was obtained as an atom bomb detonation product in the 1950s [4]. The physical half-life of I-131 is 8.6 days, the biological half-life is 80 days in thyroid tissue, 12 days outside the thyroid, the effective halflife is 7.3 days in the thyroid tissue and 8 hours outside the thyroid. I-131 treatment is kind of an oral medication and it is rapidly absorbed by the system after oral ingestion. I-131 mostly concentrates in salivary glands, thyroid and gaskin mucosa while it concentrates in sweat glands with small quantities. During the treatment period, the patient is hospitalized in a lead-insulated private room. Discharge of treated patients is determined by considering dose rate measurements taken from the 1-meter distance according to the criteria mentioned in the guideline of European Atomic Energy Committee (Euratom) which published in 1998 [3]. It is known that a very significant amount of I-131 is thrown out with urine from the human body after radioiodine treatment. In accordance with the criteria of TAEK based on Euratom guideline, the patient is discharged when the dose is smaller than 30 micro $\mathrm{Sv} / \mathrm{h}$. Dose rate measurements are taken in each room where the patients treated with radionuclide during their treatment period to provide radiation safety. This study was conducted by taking test samples from telephone handset, cell phone, refrigerator, sink, remote control, interior handle of the door, floor, dining table, interior handle of toilet door, floor of toilet where three patients treated with Lu-177 PSMA and four patients treated with I-131 at İstanbul University, Cerrahpaşa Medical School, Department of Nuclear Medicine. Gamma counts obtained from these samples were used to determine contamination rates. As a method, contamination rates of the lead-insulated rooms in which the patients are hospitalized were analyzed. 


\section{MATERIALS and METHODS}

\subsection{Preparation of Whatman Filter}

In our present study, Whatman papers (Grade 1:11 $\mu \mathrm{m}$, medium flow filter paper, purchased from Sigma-Aldrich) were used to examine the amount of contamination. The pore size is $11 \mu \mathrm{m}$ (particle retention), the basis weight is 87 grams and the spread rate of the liquid on the paper is $150 \mathrm{sec} / 100 \mathrm{~mL}$. Whatman papers are quite capable of holding fine particles, i.e. they can hold sediments without occlusion. The Whatman paper has a cellulose content ( $>98 \%$ purity) that is produced from linters. It is basically used as a filter paper for flow rate measurement and routine applications. The expanded size range includes circles with a diameter in the range between $10 \mathrm{~mm}$ and $500 \mathrm{~mm}$. It is mostly preferred for purification of liquids, soil analysis and seed testing in agriculture studies.

\subsection{Patient Preparation Procedure}

Lutetium treatment is applied to the patients in lead-insulated rooms for 1-3 nights [5]. Lu-177 is given from the arm vein of the patient as a slow infusion in 30 minutes. However, the pretreatment process of I-131 is a little longer when it is compared to lutetium treatment. Radioactive iodine given as a capsule or liquid from the oral route is absorbed through the digestive tract and collected in thyroid gland cells. The radiation originating from iodine impedes the growth and the activity of the thyroid cells. The overactive thyroid gland function returns to work normal or undesired thyroid tissue disappears. Radioiodine is mostly excreted from the body via the urinary tract and the other part is excreted by saliva, sweat, and stool. Those that can not excrete from the body will disappear after a while due to the physical half-life of the radioactive material. This period usually ends from 10 to 30 days. The length of stay in the body is shorter at lower doses, however; it is more at higher doses.

While radioactive iodine therapy for the hyperthyroid disease is usually given for outpatients, hospitalization may be required in some special circumstances. The substance given for the treatment is the radioactive iodine salt. The radiation risk of iodine salt is low for patients and relatives. I-131 therapy should not be applied to pregnant women according to the ICRP protocols and treatment response should not be expected before 4-6 weeks [6]. In order to further increase the activity of radioactive iodine given to the patient, low iodine diet is required for 2 weeks. It is not recommended to consume iodine-containing multivitamins, all kinds of shellfish (including mussels, shrimps, crabs, lobsters, and so forth) and iodized salt 2 weeks before the treatment date [7]. Patients should not be allowed to use tincture iodines or similar antiseptics on their skin during at least 2 weeks. In addition, kidney film 2 months before the treatment date and gallbladder film after the first 4 months of medication should not be taken by computerized tomography. The radioactive iodine aimed to be given for the treatment is colorless, odorless and tasteless and is applied on an empty stomach and the patient should not consume something for at least 1 hour after medication process. At least 2 liters of liquid should be taken during the first 24 hours to increase iodine urination. Interior iodine is also expelled by sweat, saliva, and feces. All patients who received I-131 and Lu-177 PSMA treatment were discharged after one day in the hospital. In this study, $50 \mathrm{mCi}, 100 \mathrm{mCi}, 100 \mathrm{mCi}, 100 \mathrm{mCi}$ of I-131 radionuclides were given to the patient1, patient-2, patient-3, and patient-4, respectively. Similar to I-131 treatment, 107 $\mathrm{mCi}, 106 \mathrm{mCi}, 195 \mathrm{mCi}$ of $\mathrm{Lu}-177$ radionuclide were given to the patient-5, patient- 6 , and patient-7, respectively.

\subsection{Counting Test}

After localization of organ and radiopharmaceutical around the target region, the detector is aligned based on the geometric conditions and the count is then taken. The photons emitted from the orbit are oscillated in all directions by $360^{\circ}$ degrees. The beams falling on the detector are positioned by the collimator (director) and are sent to the scintillation crystal. 
The detector material of the scintillation crystal is sodium iodide " $\mathrm{NaI}(\mathrm{Tl})$ " compound which is generally activated by thallium. It converts photons falling on this material into photons of visible light by scintillation. The scintillations are focused by the light directing layer to reflect the photon multiplier strand (PMT). At the PMT output, scintillations which transform electrical signals are sent to consecutive electronic units to be shaped [8]. The measurement times may vary from 0.02 minutes to several hours depending on the half-life and the concentration of the sample. The gamma counter used in our study is the Compening CRC-25W well counter (see Fig. 1) and it is sodium iodide (NaI) drilled-well type crystal detector. Counter console dimensions are given in the following manner: height: $13.7 \mathrm{~cm}$, width: $26.0 \mathrm{~cm}$, depth: $26.7 \mathrm{~cm}$ and weight: $1.8 \mathrm{~kg}$ (3.9lb). The room size of the counter is given as follows: height: $43.8 \mathrm{~cm}$ (17.85 inches), diameter: $17.2 \mathrm{~cm}$ (6.77 inches), weight: $13.6 \mathrm{~kg}$ (30 lb), well diameter: $6.1 \mathrm{~cm}$ (2.4 inches), well depth: $25.4 \mathrm{~cm}$ (10.0 inches), cable length: $3.7 \mathrm{~m}$ $(12 \mathrm{ft})$. The counter screen is made up of a liquid crystal display with dot matrix. The calibrator values, the selected radionuclide, the calibration number, the measured activity and the imaging units $(\mathrm{Bq}$ or $\mathrm{Ci})$ can be selected as desired. The accuracy of the counter is about $\pm 2 \%$.

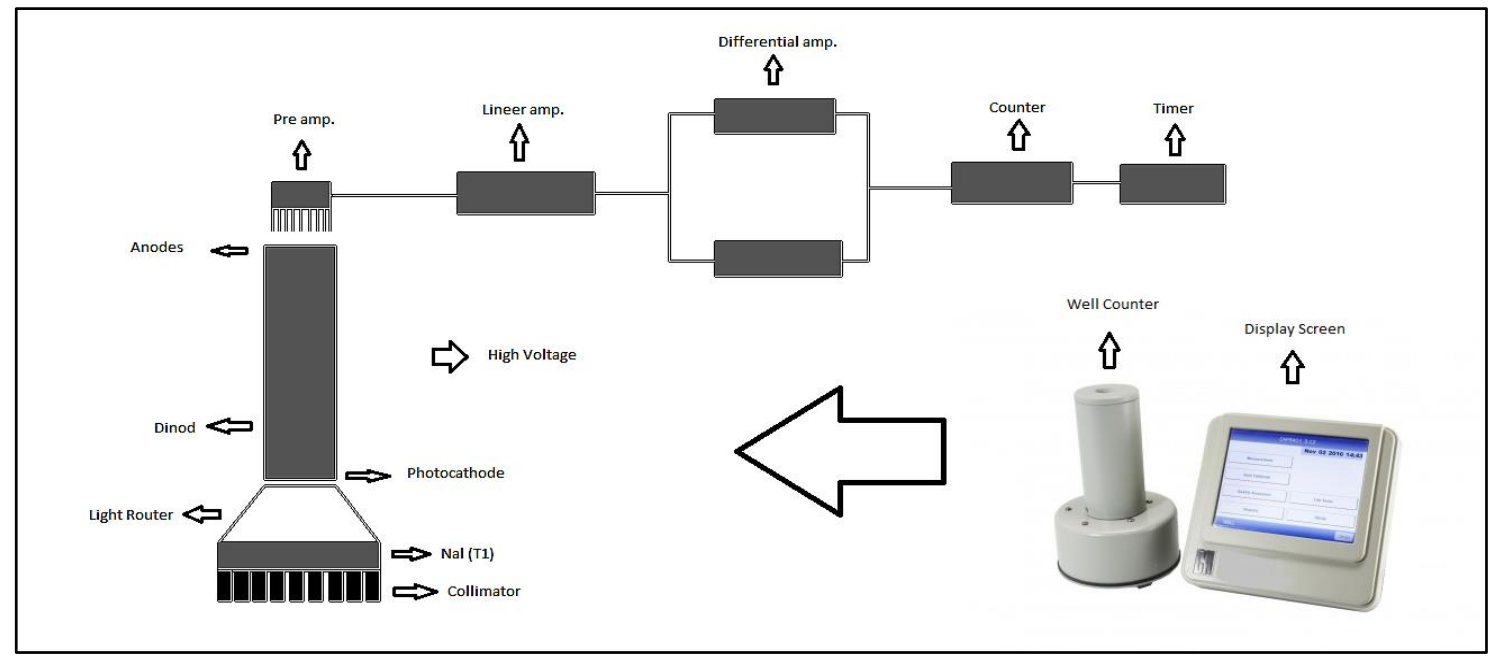

Figure 1. Schematic illustration of Compening CRC-25W Well Counter.

In this study, measurements were taken from different parts of the lead-insulated special rooms of three patients treated with $\mathrm{Lu}-177$ PSMA and four patients treated with I-131, respectively. Sweeping tests were carried out by using Whatman papers $\left(10 \times 10 \mathrm{~cm}^{2}\right.$ in size $)$ on the measured surfaces. Whatman papers were placed in different tubes to prevent external contamination. Subsequently, one-minute counts were taken by using the gamma counter with separate calibration factors for Lu-177 and I-131 radionuclides in the tubes where Whatman papers were placed. For background extraction, counting test was applied to one of the Whatman papers for one minute and background value was then obtained. Background value was measured at $1370 \mathrm{cpm}$ which approximately corresponds to 9000 counts. The 9000 counts measured in the Gamma Counter technically corresponds to 180 counts based on the $2 \%$ sensitivity ratio of the counter. Since 180 counts are obtained in the background value, the values are assumed to be zero.

\section{RESULTS and DISCUSSION}

The measurements taken from lead-insulated rooms of each patient are given in Table 1 and Table 2, respectively. The average values of dose rates measured in the patient rooms were calculated by considering the ratio of the total dose and the number of patients for each nuclide and the results were given in Fig. 2. Based on experimental results it can be said that the area with the highest contamination in the rooms of 
patients treated with I-131 radionuclide is the surface of toilet pottery. The contamination rates decrease in the following order: floor base, sink, the interior handle of the toilet door, dinner table, mobile phone, remote control, refrigerator, the interior handle of room's door, telephone handset, respectively. Apart from I-131, for the patients who treated with $\mathrm{Lu}-177$, the highest contamination has been observed on the surface of toilet pottery as well. After the surface of toilet pottery, there is a decrease in contamination rates in the following order: telephone handset, floor base, dinner table, the interior handle of the toilet door, remote control, sink, the interior handle of the room door, refrigerator and mobile phone, respectively.

Table 1. Dose rate values obtained from the rooms of patients treated with I-131 radionuclide.

\begin{tabular}{lllll}
\hline \multicolumn{5}{c}{ DOSE RATE VALUES FOR I-131 RADIONUCLIDE (cpm) } \\
\hline Simplified Fields & Patient-1 & Patient-2 & Patient-3 & Patient-4 \\
& Dose values & Dose values & Dose values & Dose values \\
\hline Telephone handset & 788 & 1332 & 468 & 788 \\
Mobile phone & 2641 & 1328 & 964 & 1504 \\
Refrigerator & 2525 & 1200 & 0 & 300 \\
Sink & 15810 & 3926 & 1180 & 1917 \\
Remote Control & 3662 & 1861 & 464 & 160 \\
Interior handle of room door & 1448 & 508 & 1665 & 372 \\
Floor Base (room) & 21510 & 12790 & 1973 & 3890 \\
Dinner Table & 6710 & 1508 & 1112 & 2761 \\
Interior handle of toilet door & 8634 & 2137 & 1320 & 1593 \\
Surface of toilet pottery & 6188 & 83720 & 1300 & 5051 \\
\hline
\end{tabular}

Ages of the patients treated with I-131 radionuclide in lead-insulated rooms were 17 , 42, 53 and 77, respectively. Dose rate measurements taken from the toilet were found to be higher since three of the patients were men and contamination arising from the urine all around the surface of toilet pottery [9]. The contamination rate was also found to be more than expected in floor base due to the use of same slippers which are already used in the toilet. In addition, $85 \%$ of the $\mathrm{I}-131$ radionuclide is largely excreted by urine, $10 \%$ of $\mathrm{I}-131$ by sweating and the remaining $5 \%$ of $\mathrm{I}-131$ by saliva $[10,11,12]$, respectively. When contaminated sites with lower dose rate values are considered, it can be said that treated patients spend much less time in those areas. Because of this fact, the dose rate values of the contaminant sites were greatly affected. The ages of the patients treated with $\mathrm{Lu}-177$ radionuclide in lead-insulated rooms were 53, 67 and 85, respectively. Two of those were male and the highest amount of contamination has therefore been observed in the toilet of the rooms. In these rooms, the highest contamination was measured on telephone handset and floor base. The lowest contamination value was obtained from the mobile phones of the patients. 
Table 2. Dose rate values obtained from the rooms of patients treated with $\mathrm{Lu}-177$ radionuclide.

\begin{tabular}{llll}
\hline \multicolumn{4}{l}{ DOSE RATE VALUES FOR Lu-177 PSMA RADIONUCLIDE (cpm) } \\
\hline Simplified Fields & Patient-5 & Patient-6 & Patient-7 \\
& Dose values & Dose values & Dose values \\
\hline Telephone handset & 670 & 1428 & - \\
Mobile phone & - & - & - \\
Refrigerator & - & 26 & - \\
Sink & 46 & 466 & - \\
Remote Control & - & 554 & - \\
Interior handle of room door & - & 310 & - \\
Floor Base (room) & 54 & 1234 & - \\
Dinner Table & 334 & 782 & - \\
Interior handle of toilet door & - & 788 & 294 \\
Surface of toilet pottery & 145600 & 24620 & 566 \\
\hline
\end{tabular}

There is a remarkable difference between gamma energies of the patients treated with the I-131 radionuclide (364 $\mathrm{keV}$ ) and $\mathrm{Lu}-177$ radionuclide $(113.208 \mathrm{keV})$ arising from the contamination by inhalation [13]. Since the halflife of the Lu-177 radionuclide is 6.7 days and the physical half-life of the I-131 radionuclide is 8.08 days, the dose rate values measured in leadinsulated rooms of patients treated with $\mathrm{Lu}-177$ radionuclide were found to be less than that of the I-131 radionuclide. $90 \%$ of the daily iodine requirement is provided by food consumption and the remaining $10 \%$ by drinking water.
Approximately $50 \%$ of the iodine in the foods is absorbed. Absorption which occurs in the stomach and intestines is completed only in one hour. Iodine is found in plasma in an inorganic form that has a level in the range between 0.1 and $0.5 \mu \mathrm{g} / \mathrm{dl}$. However, they do not stay long in case of circulation since the plasma clearance for the iodide ions of the kidneys is quite high ( $35 \mathrm{mg}$ per minute). In the first few days, a quadruplet of iodine is normally urinated $(390 \mu \mathrm{g} / \mathrm{I})$ and the remaining amount $(60 \mu \mathrm{g} / \mathrm{l})$ is selectively provided from the blood by the thyroid gland cells for the synthesis of thyroid hormones.

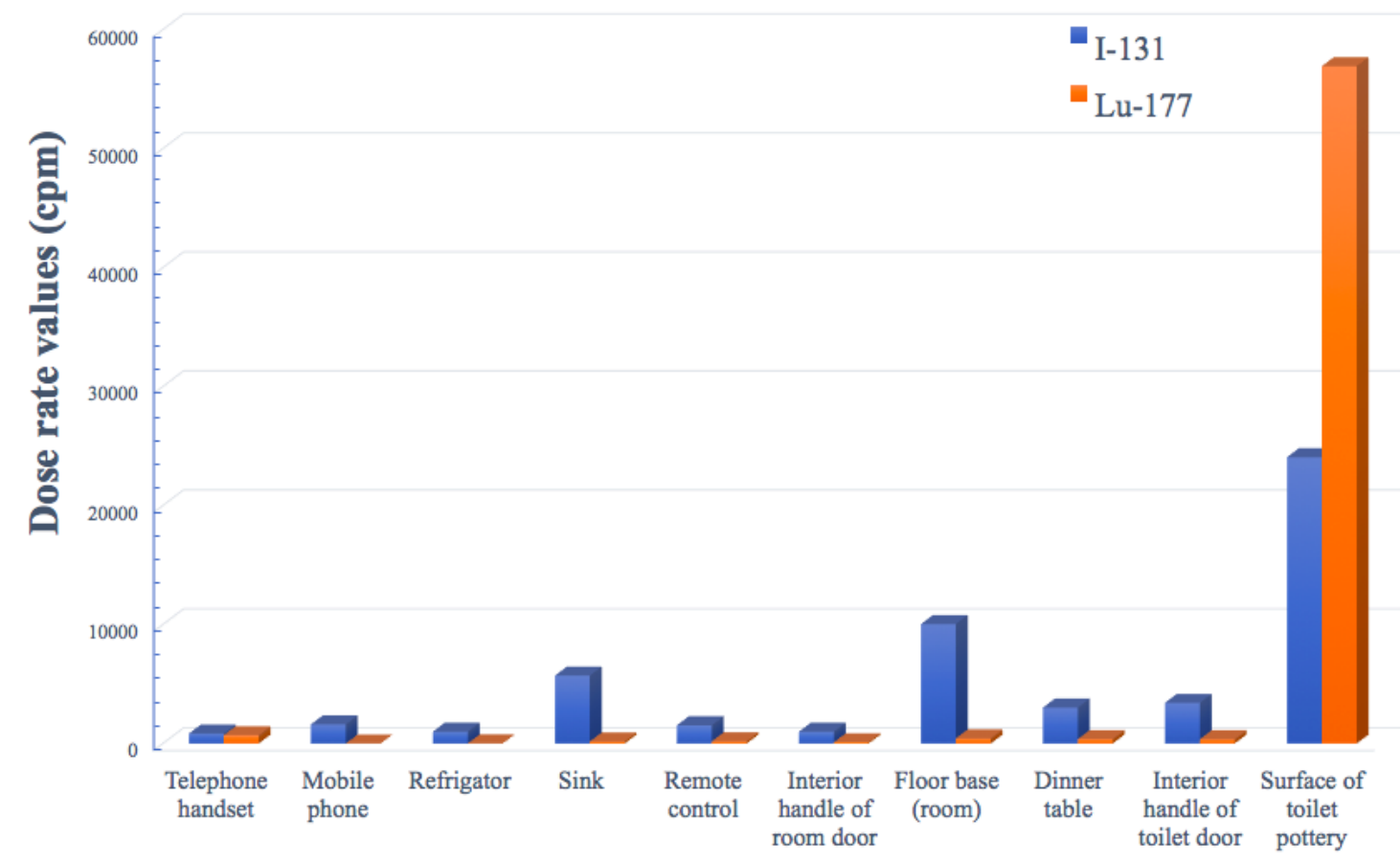

Figure 2. I-131and Lu-177 PSMA Dose Rate Values for Contaminating Fields. 


\section{CONCLUSION}

To sum up, it is clearly shown that the highest contamination rate has been found on the surface of toilet pottery in each lead-insulated room in which the patients are treated with I-131 and LU177 PSMA. Our statistical data indicates that the age and the gender of the patients as much as the area where they actively use during their treatment process can affect the contamination rates. For this reason, many numbers of contamination rate measurements and sweeping tests must be carried out by considering the equal number of genders and different age groups in order to make more comprehensive and more accurate analysis.

\section{CONFLICTS OF INTEREST}

The authors stated that did not have a conflict of interests.

\section{ACKNOWLEDGMENTS}

Two of us (Tuğba Demirbay and Kübra Harman) would like to thank Yaşar Karabul for his useful comments and fruitful discussions on this paper and Nami Yeyin for the counting measurements at Istanbul University, Cerrahpaşa Medical School, Department of Nuclear Medicine.

\section{REFERENCES}

[1]. Ahmadzadehfar H., Eppard E., Kurpig S., Fimmers R., Yordanova A., Schlenkhoff C.D., Gartner F., Rogenhofer S. and Essler M., Therapeutic Response and Side Effects of Repeated Radioligand Therapy with 177 Lu-PSMA-DKFZ-617 of Castrate-Resistant Metastatic Prostate Cancer, Oncotarget, 7 (2016) 12477 12488.

[2]. Rahbar K., Schmidt M., Heinzel A., Eppard E., Bode A., Yordanova A., Claesener M. and Ahmadzadehfar H., Response and Tolerability of a Single Dose of 177 Lu-PSMA-617 in Patients with Metastatic Castration-Resistant Prostate Cancer: a Multicenter
Retrospective Analysis, J. Nucl. Med., 57 (2016) 1334-1339.

[3]. Yeyin N., Akyel R., Abuqbeitah M., Çavdar İ., Sönmezoğlu K. and Demir M., The Evaluation of Dose Rate Measurements and Discharge Time After Radionuclide Therapy, J Ist Faculty Med., 80 (2017) 1-6.

[4]. Daniels G. H., Radioactive Iodine: A Slice of History, Thyroid, 23 (2013) 253-258.

[5]. Demir M., Radiobiological Effects, Protection of the Patient, Protection of Caregivers, Protection of Those Around the Patient and the Environment, Nuclear Medicine Seminars, 1 (2015) 3171-3190.

[6]. Casara D., Rubello D., Saladini G., Piotto A., Peiizzo M.R., Girelli M.E., Busnardo B., Pregnancy After High Therapeutic Doses of Iodine-131 in Differentiated Thyroid Cancer: Potential Risks and Recommendations, Eur J Nucl Med Mol Imaging, 20 (1993) 192-194.

[7]. Lakshmanan M., Schaffer A., Robbins J., Reynolds J. and Norton J., A Simplified Low Iodine Diet in I-131 Scanning and Therapy of Thyroid Cancer, Clin Nucl Med., 13 (1988) 866-880.

[8]. Demir M., Nükleer Tıp Fiziği ve Klinik Uygulamalar1, 3rd ed. Turkey, Chap 2.

[9]. Willegaignon J., Sapienza M., Ono C., Watanabe T., Guimarâes M. I., Gutterres R., Marechal, M. H., Buchpiguel C., Outpatient Radioiodine Therapy for Thyroid Cancer: a Safe Nuclear Medicine Procedure, Clin Nucl Med., 36 (2011) 440-445.

[10]. Sabbir A.S.M., Demir M., Yasar D., Uslu I., Quantification of Absorbed Doses to Urine Bladder Depending on Drinking Water During Radioiodine Therapy to Thyroid Cancer Patients: a Clinical Study Using MIRDOSE3, Nucl Med Commun., 24 (2003) 749-754.

[11]. Özdoğan Ö., Töre G., Özkılıç H., Kır M., Yüksel D., TSNM, Procedure Guideline for I-131 Treatment of Hyperthyroidism 
2.0., Nuclear Medicine Seminars, 1 (2015) 44-90.

[12]. Driver I., Packer S., Radioactive Waste Discharge Quantities for Patients Undergoing Radioactive Iodine, Nucl Med Commun., 22 (2001) 1129-1132.

[13]. Schneider, A. B., Radiation and Thyroid

Cancer. In: Braverman L.E. (Ed.) Diseases of the Thyroid. 2nd ed. Berlin: Springer, pp (2003) 239-262. 